\title{
THE LECTURE NOTES OF ST. GEORGE TUCKER: A FRAMING ERA VIEW OF THE BILL OF RIGHTS
}

\author{
David T. Hardy*
}

Few if any legal figures in the early republic held the status of St. George Tucker. Educated in the law by William and Mary's George Wythe, Tucker succeeded him as the College's professor of law, a post he held from 1790 until his appointment to the bench in 1804. ${ }^{1}$ While at William and Mary, he produced an edition of Blackstone's Commentaries, ${ }^{2}$ annotated in light of American law. The text became "the standard work on American law for a generation" and Tucker remained the most frequently cited American legal scholar for over two decades. ${ }^{3}$ Tucker's role in American legal scholarship was likewise striking. He has been termed "the first modern American law professor" and creator of the American law degree. ${ }^{4}$

Tucker had exceptional opportunity to observe the legal events at the Founding. His closest friend, John Page, and his brother Thomas Tucker served in the first House; they and others kept him informed, by correspondence, of its events. ${ }^{5}$ He was temperamentally suited to analyze the Framing period. His edition of the Commentaries was far from a reprint of the original; Tucker documented at length where the American States had refused to adopt common law principles, and where the new Constitution and Bill of Rights diverged from them. ${ }^{6}$ While Blackstone had seen the com-

\footnotetext{
J.D., University of Arizona 1975.

1 See generally Craig Evan Klafter, St. George Tucker: The First Modern American Law Professor, 6 J. HIST. SOC. 133 (2006).

2 St. George Tucker, Blackstone's Commentaries with Notes of Reference, to the Constitution and Laws of the Federal Government of the United States and of the COMmonwealth OF VIRGinia (St. George Tucker ed., Lawbook Exchange, Ltd. 1996) (1803) [hereinafter TUCKER's BLACKSTONE], available at http://www.constitution.org/tb/tb-0000.htm (link).

3 Paul Finkelman \& David Cobin, Introduction to 1 TUCKER's BLACKSTONE, supra note 2, at xii.

${ }^{4}$ Klafter, supra note 1, at 133, 145-46. Klafter identifies the American law degree as unique among common law jurisdictions in that its holder has received a broad education in the law and is capable of practicing without further training. See id. at 145-46.

5 See 1 AnNAls of Cong. 95 (Joseph Gales \& W.W. Seaton eds., 1834) (Mar. 4 \& Mar. 14, 1789), available at http://memory.loc.gov/cgi-bin/ampage?collId=llac\&fileName=001/llac001.db\&recNum=51 (listing Thomas Tucker and John Page as Congressmen from South Carolina and Virginia, respectively) (link); Mary Haldane Coleman, St. George Tucker: Citizen of No Mean City 35, 113-14 (1938); see also CREATING the BILl of Rights: THE Documentary ReCORD From the First FEDERAL CONGRESS 293, 300 (Helen E. Veit et al. eds., 1991) (providing examples of letters from Thomas Tucker and John Page keeping St. George Tucker apprised of developments in the Congress).

${ }^{6}$ See Klafter, supra note 1, at 142.
} 


\section{NORTHWESTERN UNIVERSITY LAW REVIEW COLLOQUY}

mon law as supra-personal and beyond improvement, Tucker delighted in documenting how Americans of his time had improved upon it and eliminated its shortcomings. ${ }^{7}$

Largely forgotten today, Tucker returned to some legal prominence last Term, when the majority in District of Columbia v. Heller ${ }^{8}$ cited his annotated Blackstone's Commentaries as proof that the Second Amendment had originally been understood as an individual right to arms. ${ }^{9}$ The dissent also invoked Tucker's lecture notes to argue that, during the Framing period, he had seen it as a militia-related right of States. ${ }^{10}$

Tucker taught his law students from extensive handwritten lecture notes, compiled in bound volumes. His notes were preserved, and today are archived in the Tucker-Coleman Collection of the Earl Gregg Swem Library at the College of William and Mary. ${ }^{11}$ The following is a transcription of the portion dealing with the Bill of Rights, which follows Tucker's discussion of the limits placed upon Congress by Article I, Section 10. The main text appears to date from 1791-92, with some marginal notes added later. ${ }^{12}$ Given his position and their dating, Tucker's notes are exceptional evidence of original public understanding and indispensible tools for originalist interpretation.

Given contemporary adherence to originalist interpretation, and the likelihood of future conflict — as demonstrated in Heller-between varieties of originalist analysis, dissemination of Tucker's hitherto unpublished lecture notes ${ }^{13}$ may offer an important contextualization of the Bill of Rights during the Founding period. It is my hope that working to democratize, as it were, the availability of these documents will assist future historical and

7 See id. at $140-43$.

8 128 S. Ct. 2783 (2008).

9 Id. at 2805.

${ }^{10} I d$. at 2839 n.32 (Stevens, J., dissenting). The majority's response, id. at $2805 \mathrm{n} .19$, assumes that the passage quoted by the dissent is in fact Tucker's discussion of the Second Amendment. In this both majority and dissent were misled. See infra Part II.

11 Tucker's legal papers are presently being edited into a two-volume edition, due for publication in 2011. Omohundro Institute of Early American History \& Culture, http://oieahc.wm.edu/tucker/index.html (link).

${ }^{12}$ Tucker refers to the Bill of Rights as ratified, which places the notes at 1791 or later. Earlier in his notes he devotes a lengthy discussion to whether the States may arm the militia if Congress failed to do so, a point mooted by enactment of the Militia Act of 1792, 1 Stat. 271. St. George Tucker, Ten Notebooks of William and Mary Law Lectures 126-28 [hereinafter Tucker, Law Lectures] (unpublished Tucker-Coleman Papers, located at the Earl Gregg Swem Library at The College of William and Mary) (copies on file with the Northwestern University Law Review). But the marginal note at page 145 refers to the Alien Act of 1798, 1 Stat. 570, indicating that some such notes were later additions. See infra note 34 and accompanying text.

13 I have located only two mentions of Tucker's lecture notes. Professor Klafter refers to them in discussing Tucker's teaching technique, and quotes one paragraph. Klafter, supra note 1, at 141-42 \& nn.42-46. Professor Cornell briefly discusses their relevance to the right to arms and quotes one paragraph. Saul Cornell, St. George Tucker and the Second Amendment: Original Understandings and Modern Misunderstandings, 47 WM. \& MARY L. REV. 1123, 1129-30 (2006). 
legal analysis.

In the following transcript, Tucker's words are italicized and indented. Indecipherable words are denoted by blanks, and probable but uncertain ones by brackets. Tucker refers to the Amendments by their original numbering, identifying the First Amendment as the Third Article. His original "footnotes" (actually written on the blank facing pages) are so identified. His pagination (which is consecutive throughout the books) is in brackets. For ease of access, I have prefaced Tucker's remarks with the relevant Amendment and, where salient, a brief introduction.

Tucker begins by itemizing the restrictions upon Congressional power found in Article I, Section 10, and then turns to those imposed by the Bill of Rights.

\section{AMENDMENT I}

\section{A. Religion}

Tucker takes a very robust view of freedom of religion and the Establishment Clause; separation of government and religion is indispensable to domestic tranquility. The words he uses to describe the concept-"[T]o separate them by mounds which can never be overleap'd"-resembles Jefferson's later and more elegant invocation of "a wall of separation between Church and State." 14 Whether Jefferson took the metaphor from Tucker, with whom he was in frequent contact and considered among his "earliest and best friends," 15 will never be known. It has been argued that a more likely source is the English Whig writer James Burgh, who referred to "an impenetrable wall of separation between things sacred and civil." 16 Whatever the ancestry of Jefferson's words, Tucker's similar phrasing suggests that metaphors of this type were not uncommon at the time. At the very least, we cannot regard Jefferson as an outlier, and thus cannot conclude that just a "few Englishmen or Americans appear to have demanded separation of church and state during the late eighteenth century . . .."17

\section{[Page 140]}

\section{The Third Article to the Amendments to the Constitution imposes several im-}

14 Letter from Thomas Jefferson to Nehemiah Dodge, Ephraim Robbins \& Stephen S. Nelson (Jan. 1, 1802), reprinted in THE LIFE AND SELECTED WRITINGS OF THOMAS JEFFERSON 332 (Adrienne Koch \& William Peden eds., 1944).

15 David T. Hardy, Armed Citizens, Citizen Armies: Toward a Jurisprudence of the Second Amendment, 9 HARV. J.L. \& PUB. POL'Y 559, 612 (1986).

16 See Daniel L. Dreisbach, Thomas JefFerson and the Wall of Separation Between Church and State 81 (2002); IsAaC Kramnick \& R. LAurence Moore, The Godless Constitution: The CASE AgAinst Religious CoRrectness 83 (1996).

17 Philip Hamburger, SeParation of Church and State 59 (2002). 


\section{NORTHWESTERN UNIVERSITY LAW REVIEW COLLOQUY}

portant restrictions on the legislative authority of the Federal governmentviz.

8. Congress shall make no law respecting an establishment of religion, or prohibiting the free exercise thereof.

Our State bill of rights, art, 16, contains the following axiom-that religion, or the duty we owe to our Creator, and the manner of discharging it, can be dictated only by reason and conviction, not by force or violence. In vain may the civil magistrate interpose the authority of human laws to produce that conviction

[P. 141]

which human reason rejects: in vain may the secular arm be extended to realize the fortunes denounced against unbelievers by all the various sectarists of the various denominations of religion throughout the world. It is not in the power of human laws to convince though it ${ }^{18}$ to torture and to punish. Hence the numberless persecutions, martyrdoms and massacres, which have stained the annals of mankind, from the first moment that civil and religious institutions were blended together-To separate them by mounds which can never be overleap'd, is the only means by which the peace of mankind, and the genuine fruits of charity \& fraternal love can be preserved. This prohibition may therefore be considered as the [cement?] of government as well as the guarantee of happiness to the individual. See Acts of 1785 c, [2 or 3? 4]. ${ }^{19}$

\section{B. Speech and Press}

The American concept of freedom of expression was, in Tucker's time, undergoing a transition. Some held to the view that it went no further than prior restraint: writers took the risk of seditious libel prosecutions, or civil actions, once they were in print. Others were beginning to see freedom of expression in a broader light, a view that did not really take hold until the Sedition Act of $1798 .^{20}$

Tucker is ahead of his time, taking a robust view of Americans' rights. Even in time of "national struggles" limitations on freedom of expression are traps rather than benefits and marks of tyrannical tendencies; Tucker cites as illustrative Virginia's wartime limit on pro-British expression. Tucker's reference to freedom from exemption from "coercion" brings to mind the modern concept of "chilling effects." In all these things, the eigh-

18 "Is" appears to be omitted here.

19 Most likely 24. The Act to Establish Religious Freedom formed chapter 24 of the Virginia laws of 1785. See An Act for Establishing Religious Freedom (1785), reprinted in 12 STATUTES AT LARGE; Being a Collection of All the LaWs of Virginia, FROM the FirSt SeSSiOn OF THE LEgislature, IN THE YEAR 1619, at 84 (William W. Hening ed., 1823) [hereinafter HENING, LAWS OF VIRGINIA], available at http://www.vagenweb.org/hening/index.htm (link).

20 LEONARD W. LEVy, ORIGINS OF THE BILL OF Rights 104-32 (1999). 
teenth-century academic is surprising modern: he seeks no "clear and present danger" test, even in wartime. While we cannot know how he would view modern issues such as obscenity, civil defamation, or political campaign regulation, his equation of freedom of thought with freedom of expression, and his repudiation of wartime Virginia statutes suggests that he would find the modern First Amendment tests, if anything, to be overly permissive of regulation.

9. Congress shall make no law abridging the freedom of speech, or of the press.

As human laws are incapable of producing conviction on the human mind, neither can they without violating the most important of human rights control the expression of whatsoever our reason dictates. The liberty of speech in inseparable from liberty of thought. Both are the immediate gift of the Creator, and are equally entitled to exemption from coercion by any earthly power.

\section{[P. 142]}

Restraints on the freedom of speech are the unequivocal marks of a tyrannical principle in government where they are imposed.-They have been resorted to in almost every nation, especially during the times of national struggles; but they are rather traps than fetters.

[Tucker note: See the Acts of this Cwealth for punishing certain offenses Acts 1776. Ch :5. "If any person residing within this $C w$ shall by any word, open deed, or act, [advisedly?] \& [illegally or willingly?] defend the authority, jurisdiction or power of the king or parliament as heretofore claimed and experienced within this colony, or shall attribute any such authority to the king $\& c$., the person offending, being legally convicted, shall be punished by fine \& impr. To be [assessed by?] a jury, so as the fine shall not exceed L 20,000, nor the imprisonment the term of five years. See the [Little?] Rev. Code 40.]

The freedom of the press, says our own State bill of rights, is one of the greatest bulwarks of liberty \& can never be restrained but by despotic govern'ts.

Since the introduction of art of printing the rights of mankind, \& the reasonable limits of the powers of government, have been, if not better, at least more generally, understood than at any former period, since the commencement of human annals. [Tucker note: De Lolme [Jean de Lolme, The Rise and Progress of the English Constitution (1781)] considers the freedom of the press as a [censorial?] power actually residing in the people. [Pa?] 212. The liberty of the press consists in this, that neither the courts of justice, nor any other [judges?] whatsoever, are authorized to [take notice?] of writings intended for the press, [but] are confined to those which are [actually?] printed $\&$ must in their [case proceed?] by the trial by jury. Ibid. 215. $]^{21}$

21 In modern terms, no prior restraint: a libel prosecution could only be brought after publication. 2 


\section{NORTHWESTERN UNIVERSITY LAW REVIEW COLLOQUY}

-In England, where the freedom of the press flourished more than in any part of Europe, the nation has consequently enjoyed a greater portion of freedom. In America, where the freedom of the press was still less restrained, we may venture to pronounce that the people, from that source alone, have so far as related to the internal administration of the government always enjoyed a greater portion of liberty, even before the revolution, than the State itself. Since that period, our [enemies?] have endeavored to disseminate opinions that our liberty has become licentiousness. - This is a calumny which the peaceable demeanor of the people \& the regular administration of justice, daily contradict and refute. The liberty of the press, will I trust, secure togenerations that portion of liberty which is now enjoyed among us, unsullied, undiminished, and unimpaired.

\section{Assembly and Petition for Redress of Grievances}

Tucker here argues the First Amendment's language is too narrow: the citizenry should be able, not only to petition, but to instruct, their legislators. The right to instruct had been guaranteed in several State constitutions, and in the First Congress, Tucker's brother Thomas proposed its addition to the Federal Bill of Rights. ${ }^{22}$

[P. 143]

10. The same article provides that Congress shall make no law abridging the right of the people peaceably to assemble, and to petition the government for the redress of grievances. The bill of rights proposed by the Convention of Virga article 15 expresses that right in terms better adapted to the nature of a representative government, administered by the servants of the people \& not by rulers who are their lords, by declaring, that the people have a right peaceably to assembled together to consult for their common good, or to instruct their representatives, and that every freeman has a right to petition or, or apply to the legislature for redress of grievances. This is the language of a free people asserting their rights: the other [savors?] too much of that state of condescension observable in the acts of those rulers who affect to grant, what they cannot with-hold. [Tucker note: In England it is provided by Statute 13 Car: 2 c. 5 that no petition to the king or either house of parliament, for any alterations in church or state, shall be signed by above twenty persons, unless the matter thereof be approved by three justices of the peace, or the major part of the grand jury in the county-hence I presume arose the custom of grand juries presenting public grievances in this country.-The same statute declares that no petition shall be presented by more than [ten?] persons. 1 B.C. [Blackstone's Commentaries] 143.]

\section{AMENDMENT II}

The present controversy over the Second Amendment relates to wheth-

\footnotetext{
JEAN Louis DE LOLME, THE Rise AND PROGRESS OF THE ENGLish CONSTITUTION, ch. 9 (1781).

22 AKhil Reed Amar, The Bill of Rights: Creation AND ReCONSTRUCTION 28-29 (1998).
} 
er it protects a right to arms for individual purposes such as self-defense, or only a right to arms when serving in an organized militia. Last Term, in District of Columbia v. Heller, the Supreme Court ruled for the former interpretation. The Heller ruling was a narrow five-to-four.

Tucker's lecture notes provide strong evidence for the Heller majority. He considers the right to arms the palladium (in eighteenth-century terms, the ultimate protection) of liberty and to be derived from the natural and individual right of self-defense.

One wonders how the Stevens dissent in Heller could have argued, from these lecture notes, that "St. George Tucker, on whom the Court relies heavily, did not consistently adhere to the position that the Amendment was designed to protect the 'Blackstonian' self-defense right ..." or that the notes suggest the Second "Amendment should be understood in the context of the compromise over military power represented by the original Constitution and the Second and Tenth Amendments."23

The brief answer appears to be that the dissent relied uncritically on the portions of the lecture notes quoted by Saul Cornell in a 2006 article, ${ }^{24}$ which the dissent cites as authority. ${ }^{25}$ The article sets out the quotations cited by the dissent and argues that they reflect Tucker's "earliest formulation of the meaning of the Second Amendment," and "casts the right to bear arms as a right of the states." 26

In fact, the article's quotations are misleading; they come from Tucker's discussion of the militia clauses of the original Constitution, which predictably deal with military power and the States. Tucker argues that the States have the power to arm their militias should Congress not do so since such power is not forbidden to States by the Constitution and hence is protected by the Tenth Amendment, just as any arms given would be protected by the Second Amendment. ${ }^{27}$ When, less than twenty pages later, Tucker does discuss the Bill of Rights, the language he uses closely parallels his 1803 Blackstone's Commentaries, usually down to the word. ${ }^{28}$

The right of the people to keep and bear arms shall not be infringed-this may be considered as the palladium of liberty. The right of self defense is the first law of nature. In most governments it has been the study of rulers to abridge this right with the narrowest limits. Where ever standing armies are kept up \&

23128 S. Ct. 2783, 2839 n.32 (2008).

24 Cornell, supra note 13.

$25128 \mathrm{~S}$. Ct. at 2841.

26 Cornell, supra note 13, at 1130.

27 Tucker, Law Lectures, supra note 12, at 127-29.

28 E.g., Tucker's Blackstone begins its discussion of the Second Amendment with "The right of self defence is the first law of nature: in most governments it has been the study of rulers to confine this right within the narrowest limits possible. Wherever standing armies are kept up, and the right of the people to keep and bear arms is, under any colour or pretext whatsoever, prohibited, liberty, if not already annihilated, is on the brink of destruction." Tucker then proceeds to a condemnation of the British game laws. 1 TUCKER's BLACKSTONE, supra note 2, app. note D, at 300. 


\section{NORTHWESTERN UNIVERSITY LAW REVIEW COLLOQUY}

the right of the people to bear arms is by any means or under any colour whatsoever prohibited, liberty, if not already annihilated is in danger of being so.In England the people have been disarmed under the specious

[p. 144]

pretext of preserving the game. ${ }^{29}$ By the alluring idea, the landed aristocracy have been brought to side with the Court in a measure evidently calculated to check the effect of any ferment which the measures of government may produce in the minds of the people.—The Game laws are a [consolation?] for the government, a rattle for the gentry, and a rack for the nation.

[Tucker note: In England the right of the people to bear arms is confined to protestants - and by the terms suitable to their condition \& degree, the effect of the Declaration is entirely done away. Vi: Stat. $1 \mathrm{~W} \& M l: 2$ c. 2.$]^{30}$

\section{AMENDMENT III}

The Third Amendment is the "nonstarter" of the Bill of Rights: in two centuries, precisely one case ${ }^{31}$ has had cause to seriously consider it (the suit failed on qualified immunity grounds, the Second Circuit finding that, unsurprisingly, its dimensions were not clearly established). Tucker is rather skeptical here, seeing the guarantee as evidencing a tolerance of standing armies.

12. No soldier shall in time of peace be quartered in any house without the consent of the owner; nor in time of war but in the manner prescribed by law.

This clause by a kind of side wind seems to countenance the keeping up a standing army in time of peace; on which subject we have already offered some remarks. It is calculated in some measure to lessen the burden of the to the individual, but by no means to add to the security of the nation.

\section{AMENDMENT IV}

Tucker's understanding of the Fourth Amendment is interesting from a historical standpoint. The Supreme Court has long considered the Amendment's warrant requirement as a subset of reasonableness - that is, a warrantless search is, unless justified, unreasonable and thus unconstitutional

29 Tucker's understanding of the British game laws was dated. The Game Acts forbade all but major landowners from hunting or owning tools that might be used for poaching. The 1671 Game Act added firearms to that list, but they were deleted by the 1692 Game Act. See Joyce LeE Malcolm, To KEEP AND BEAR ARMS: THE ORIGINS OF AN ANGLO-AMERICAN Right 69-75, 125-26 (1994).

30 It is noteworthy that Tucker sees the Second Amendment as far more extensive than the British guarantee, whose qualifications in his eyes rendered it nugatory. Tucker's favorite thesis is that, while American rights may have British common law origins, Americans' rights-consciousness has advanced far beyond them.

31 Engblom v. Carey, 677 F.2d 957 (2d Cir. 1982). 
even if probable cause existed. ${ }^{32}$ Professor Akhil Reed Amar has argued that the Fourth Amendment's warrant or probable cause requirement stems from the legal immunity given the person executing the search, protecting against the original strict liability for an unreasonable search. Hence, probable cause was originally intended only to apply to searches authorized by warrants; warrantless searches need only be "reasonable." 33 Tucker's discussion appears to be to the contrary, treating probable cause and warrant issuance as components of reasonableness.

13. The right of the people to be secure in their persons, houses, papers \& effects, against unreasonable searches and seizures, shall not be violatedWhat shall be deemed unreasonable searches and seizures. The same article informs us, by declaring, "that no warrant shall issue, but first, upon probable cause-

[P. 145]

which cause secondly, must be supplied by oath or affirmation; thirdly the warrant must particularly described the place to be searched; and fourthlythe persons, or things to be seized. All other searches or seizures, except such as are thus authorized, are therefore unreasonable and unconstitutional. And herewith agrees our State bill of rights-Art. 10.

[Tucker note: "vi: Act concerning aliens-contra 5: Cong: c: "34]

The case of general warrants, under which term all warrants except such as are above described are included, was warmly agitated in England about thirty years ago-and after much altercation they were finally pronounced to be illegal by the common law-see [Release?] of Money v. Leach 3 Burrow 1743. 1 Bl. Rep: 555; vi 4 B.C. 291.

But this clause does not extend to repeal, or annul the common law principle that offenders may in certain cases be arrested, even without warrant. As in the case of riots, or breaches of the peace committed within view of a Justice of the Peace, or other peace officer of a county, who may in such cases cause the offender to be apprehended, or arrest him, without warrant.

Nor can it be construed to restrain the authority, which not only peace officers, but every private person possesses, by the common law, to arrest any felon if they shall be present when the felony is committed,

32 See Johnson v. United States, 333 U.S. 10, 14-15 (1948).

33 AMAR, supra note 22, at 68-71.

34 In "Of the Constitution of the United States," note D to the appendix to his Blackstone, Tucker adds at this point an argument that the Alien Act, ch. 58, 1 Stat. 570, (1798) (expired 1800), passed by the Fifth Congress, violates the Fourth Amendment. See 1 TUCKER's Blackstone, supra note 2, app. note $\mathrm{D}$, at $301-04$. 


\section{NORTHWESTERN UNIVERSITY LAW REVIEW COLLOQUY}

\section{AMENDMENTS V, VI, VII}

\section{A. Criminal Rights}

Tucker's discussion of the criminal aspects of these amendments is cursory. He makes clear, however, that he feels the right to jury trial could bear expansion, to ensure that jurors are chosen from the vicinage rather than the State. In the early Republic, this would have meant that a defendant was essentially judged by jurors who knew him and the party bringing charges, and the reputation of both.

14. The invaluable privilege of trial by jury is secured by the $7 \& 8$ articles of the Amendmts, concerning the antiquity and excellence of this mode of trial,

[P. 146]

as well in civil as in criminal cases. I shall for the present refer to 3 B.C. 349 to 3_5-4 B.C. 349 to 364 . -

An objection however may be made that the 8th Article provides only for a trial by a jury of the State \& district wherein the crime is alleged to have been committed, instead of a jury of the vicinage, which term vicinage seems to imply in our State the county at large \& not the immediate neighborhood-and I must confess that I am among the number of those who doubt the propriety of this departure from the strict common law principles.

The common law maxim, that no man is to be brought into jeopardy of his life, more than once for the same offence, is rendered a fundamental law of the gov't by the same article, as is also that other inestimable maxim of the common law, that no man should be compelled in any criminal case to give evidence against himself. That he shall moreover be informed of the nature \& cause of the accusation, be confronted with the witnesses against him, and have compulsory process for obtaining witnesses in his favor, \& have the assistance of counsel for his defence,-And that he shall in no case be deprived of life, liberty, or property without due process of law-\& herewith again agrees our own State bill of rights.

The importance of all of these articles will more evidently appear, in the course of our examinations of the subjects to which they relate, in the fourth book of the Commentaries-I have enumerated them above only for the sake of method.

15. The right of trial by jury in civil suits at common law is also [secured?] by the 9th article of the ratified amendments in all cases where the matter in controversy should exceed the value of twenty dollars. Here again I must refer the student to 3 B.C. 349 to 385. 


\section{B. Taking of Property}

Tucker interestingly ties the Fifth Amendment's takings clause to Revolutionary War impressments of supplies and equipment. Supplying armed forces had long been a problem approached through the impressment power (Virginia statutes authorizing impressments date as far back as $1677^{35}$ ). A 1781 statute authorized the governor to impress clothing, equipment, slaves, and horses for military use, adding that all property taken shall be appraised by two neutral persons with a certificate given to the owners, and "[a]ny person making impressment contrary hereto shall forfeit and pay double the value of the thing impressed." ${ }^{\prime 36}$

Tucker's understanding of the purpose of the takings clause sheds at least some light on the issue raised in Kelo v. City of New London, ${ }^{37}$ relating to whether property may be taken for private but publicly beneficial use. The Virginia impressment statutes related solely to public use, and the earliest of them barred takings for public use or otherwise.

[P. 147] $]^{38}$

17. Private property shall not be taken for public use without just compensation. Art: 7.

This article is intended to restrain the arbitrary \& oppressive measure of obtaining supplies by impress't as were practiced during the last war, not infrequently without any compensation whatsoever. A law of our own State, describes in what cases impress may be made, \& by whom: and authorizes the commitment of the offender, in case of illegal impresses.

\section{AMENDMENT VI}

Tucker, as with other rights related to criminal procedure, is cursory here. One might suppose that his heart lay with the civil rather than the criminal side of law practice.

[P. 147]

35 An Act Restrayning the Impresse of Tymber, \&c. (1677), reprinted in 2 HENING, LAws OF VIRGINIA, supra note 19, at 415 (forbidding impressments of timber "for the publique use or other purpose, use, or intent"). A later statute authorized militia officers, called out to deal with invasion or insurrection, to impress boats, carts, digging implements, as well as sailors, blacksmiths and carpenters. An Act for Making More Effectual Provision Against Invasions and Insurrections (1727), reprinted in 4 HENING, LAWS OF VIRGINIA, supra note 19, at 197.

36 An Act for Giving Certain Powers to the Governour and Council, and for Punishing Those Who Shall Oppose the Execution of Laws (1781), reprinted in 10 HENING, LAWS OF VIRGINIA, supra note 19, at $413-16$.

37545 U.S. 469 (2005).

38 We break here with Tucker's sequence; in the original he discusses takings after discussing the Sixth Amendment. See Tucker, Law Lectures, supra note 12, at 145-47. 


\section{NORTHWESTERN UNIVERSITY LAW REVIEW COLLOQUY}

16. Art:10 provides that excessive bail shall not be required; nor excessive fines imposed; nor cruel \& unusual punishments inflicted.

These restraints against oppression are well adapted to the nature of our government, and correspond exactly with the declaration contained in our own State bill of rights. Art. 9.

\section{AMENDMENTS IX AND X}

Tucker's discussion of the Ninth Amendment stresses its importance. He displays admiration for Publius, the then-anonymous authors of The Federalist, but not for their position denying the necessity of a bill of rights. Tucker's justification of a bill of rights includes its explaining to every citizen the nature of their rights, a consideration that underscores original public meaning as an interpretative approach. Tucker's treatment of the Tenth Amendment foreshadows later conflicts over Federal pre-emption, and the dormant Commerce Clause.

18. The 11th Article declares that the enumeration in the Const. of certain rights, shall not be construed to deny or disparage other rights retained by the people.

The want of a bill of rights was strongly, \& with great energy \& force of [reasoning?] [insisted on?] by the [opponents?] of the C.U.S. in its original form. The author of the letters signed by Publius [roundly?] asserts that a bill of rights was not only unnecessary but would be dangerous. His [reasoning?], as on most other points, is extremely __ \& acute, but by no means so convincing as many other parts of his letters. A bill of rights may be considered in two points of view, first as giving law to the government to be established, \& secondly, as giving information to the people. The objection to a bill of rights in the former view would apply to every written constitution. As to the second point, a bill of rights reduces to obvious fundamental maxims, [perceptible?] to every man of the commonest

[P. 148]

understanding, what can only be discovered in the consequence of learned \& deep research \& inquiries into the principles of [the laws?], without such aid.-I cannot therefore subscribe to the doctrine, ingenious as the [argument?] in favor of it must be acknowledged to be.

The amendments proposed \& ratified by the States are most of them such as would have formed the basis of a bill of rights-that they are not altogether [extensive enough?] will appear to them who will candidly examine those which were offered by this State, New York, North Carolina \& Rhode Island, which I believe includes the whole that were offered by other States.

19. Lastly, it is declared that the powers not delegated to the U.S. by the C. nor prohibited to the States, are reserved to the States, respectively, or to the 
people. Art: 12.

This article has been thought liable to some objection from a degree of equivocation in the use of the disjunctives, nor \& or. I have not [words crossed out] ___ _ the objection. But I should conclude the sense to be, that every necessary power of government, not prohibited to the States, may be exercised by the State governments, concurrently with the United States, or independent thereof according to the subject. Now by the word prohibited in this article, I understand first, such powers as by the very terms of the Constitution are taken away from the States expressly: such for example as that of coining money, as also the other powers enumerated in Art. I S. 10-

[P. 149]

Secondly, such as are in express terms granted to the United States, and are not in their nature susceptible of a concurrent authority in the individual States, such as the power to define or punish piracies \& felonies committed on the high seas, and offenses against the law of nations. The right of creating \& appointing to offices under the U.S.—All other powers necessarily springing from the very act of establishing a government, such as the powers of directing the course of inheritance, and of defining and punishing offenses agst. the society, other than such as are [entrusted?] to the declarations to Congress \& all others of a similar description, I apprehend are [secured?] to the States-such of them as are enumerated in the Constitution and are susceptible of a concurrent authority the States may possess in that manner. Such of them as are not enumerated, they will [possess?] exclusively of the U.S. - Such powers as are neither enumerated in the Constitution of the U.S. nor in the State Constitutions, nor necessarily spring from the act of establishing a government, I presume remain with the people, the original grantors of all the powers of government in those States.

\section{CONCLUSION}

Tucker's lecture notes give remarkable insight into how an American jurist and academic understood the Bill of Rights immediately after its ratification. Tucker agrees with Jefferson that the Establishment Clause erects a powerful barrier between church and state, a view the Supreme Court would not take until the Twentieth Century. He sees freedom of expression as broadly, indeed absolutely, protected against federal interference, and as linked to freedom of thought. Even in wartime, he sees suppression of dissent or subversion as the path to tyranny, a view the Court would not take until 1969 (and has not fully taken to this day). ${ }^{39}$

39 Cf. Schenk v. United States, 249 U.S. 47 (1919) (upholding conviction for distributing anti-draft leaflets during World War I); Brandenberg v. Ohio, 395 U.S. 444, 447 (1969) (reversing conviction for advocating illegal behavior, but acknowledging that prosecution would be possible "where such advocacy is directed to inciting or producing imminent lawless action and is likely to incite or produce such action"). 


\section{NORTHWESTERN UNIVERSITY LAW REVIEW COLLOQUY}

Tucker views the Second Amendment as an individual right derived from the natural right of self defense, a position that the Court only accepted in 2008. ${ }^{40}$ And he describes the general Fourth Amendment reasonableness test as incorporating its warrant and probable cause requirements, a step not taken until 1948. ${ }^{41}$ Tucker's lecture notes, in brief, indicate that this Framing period scholar was astonishingly modern.

Tucker's notes guide us toward an originalism that takes a very robust view of the Bill of Rights. If he condemned measures against pro-British speech taken in the darkest days of the Revolution, it is hard to see how he would countenance modern "hate crime" legislation, campaign limitations, or other restrictions upon expressive rights. His derivation of the Fifth Amendment's takings clause from wartime impressment statutes is at least suggestive that he did not see it as permitting takings of property for private benefit. Tucker's notes may thus bring originalism in a full circle. ${ }^{42}$

40 District of Columbia v. Heller, 128 S. Ct. 2783, 2797 (2008).

41 Johnson v. United States, 333 U.S. 10, 14-15 (1948).

42 Originalism's first major expositor was Professor Robert Bork, who saw it as a judicial restraint. See Robert H. Bork, Neutral Principles and Some First Amendment Problems, 47 IND. L.J. 1 (1971). More recent expositors, in particular Professor Randy Barnett, have seen it as a source for expansive readings of individual rights. See RANDY E. BARNETT, RESTORING THE LOST CONSTITUTION: THE PRESUMPTION OF LIBERTY (2004). 